\title{
The Legitimacy of Economic Sanctions against Islamic Republic of Iran in the Light of International Economic Law: Legal Effects and Economics Consequences
}

\author{
Vali Golmohammadi \\ Department of International Relations, Faculty of Human Sciences, Tarbiyat Modares University, Tehran, Iran \\ Email:V.golmohammadi19@gmail.com
}

\section{Payman Imani*}

Department of International and Public Law, Faculty of Law, Tarbiyat Modares University, Tehran, Iran *Corresponding Author Email: Imani_peiman@yahoo.com

\section{Doi:10.5901/mjss.2016.v7n3s3p60}

\begin{abstract}
In contemporary international law, sanction is a tool for resolving disputes and attaining special political purposes which frequently reflects the dissatisfaction of powerful members of Security Council. Embargo has been regarded as a means of bringing force and coercion for developing the states' foreign policy and its legal effects are amongst the most controversial and ambiguous issues in international relations. In light of principle governing international laws, imposed unilateral and multilateral embargo by international organizations and superpowers against Iran is illegitimate measure with an objective to modify Iran's political behavior. The current study using UN charter provision and principles governing economic sanctions in the light of the international economic law made an attempt to investigate and elaborate on legitimacy and illegitimacy of imposed economic embargo against Iran. Hence, the existing study, in the first stage, pursues answering the following questions: how the applied embargo from UN Security Council and also unilateral embargo by U.S under principles governing international law can be explained? And what are the effects and consequences on various economic sectors and Iran's foreign policy behavior? Ultimately, the last part shed light on nuclear agreement between Iran and 5+1, easing sanction and its effect and consequences on Iran's trade and economic sectors.
\end{abstract}

Keywords: economic embargo, international economic law, legitimacy of embargo, IRI, 5+1 group.

\section{Introduction}

Following inefficiency of international societies in establishing international peace and security, UN launched its activity. Under UN charter especial attention has been allocated to cooperation and collaboration in social and economic activities, human rights, and basic liberty, interests, public welfare of globe and more importantly the foundation of this union is based upon taking preventive measure rather than after death the doctor. In accordance with obligations (duty) of each organization establishments, the most important obligation (duty) of UN that is preserving international peace and security has been assigned to Security Council under article 24 of the charter ${ }^{1}$. While in selecting members, superpowers such as U.S Russia, UK, France, and China are permanent members and possess veto power which indicates the privilege of these members over other states, generally since the establishment of UN onward, the Security Council establishment has made an attempt to take necessary measures to preserve international peace and security.

In accordance with the $6^{\text {th }}$ chapter of UN charter, UN should resolve referred issues via recommendation and based on $7^{\text {th }}$ chapter of charter, Security Council must take action in cases such as endangering peace, breach of peace, and invasion. In such cases, the council does not rely on recommendation but act through some binding enactments and measures such as using force. One of the anticipated ways, under article 41 of $\mathrm{UN}$, for bringing pressure against invaders or countries contravening peace is nonmilitary solution. In recent years, Iran has been sanctioned by U.S due to its peaceful nuclear activities. Definitely, with respect to the fact that achieving peaceful nuclear activities based on NPT is the certain right of states, in effect, then exerting force by embargoing countries is not based on defined objectives of UN charter but emanates from political partiality and old enmity, since the international atomic agency reserve the rights for peaceful enrichment of uranium for all states (Kaempfer, 1998: 54-65). Economic embargo from financial sectors to petrochemical and industrial sectors has lethal effects on various economic sectors of Iran and led to stagnation in economic and trade balance.

${ }^{1}$ Article 24 gives the Security Council "primary responsibility for the maintenance of international peace and security" and requires the Security Council to act in accordance with the UN's purposes and principles. 
Hence, the current study makes an attempt to explicate and investigate economic embargo in the light of different international law and pursue answering these questions: what are the effects and consequences of imposed embargo by UN Security Council and also unilateral sanction by U.S on various economic sectors and Iran's foreign policy behavior? Finally, the current study in concluding section elaborate on the nuclear agreement between Iran and 5+1 group and easing sanctions and its effects and consequences on Iran's various economic, trade and industrial sectors.

\section{Theoretical framework; Sanction in the Light of International Law}

Economic sanctions could be considered as wrathful measures taken against one state or couple of states with the objective to modify and change the policy of the targeted state or either can be defined at least as an indicator of the embargoing states' intentions vs. embargoed states. I.e., economic embargo is the planned (programmed) measures by one or couple of state parties via restricting economic relations in order to bring pressure on the targeted states which accompanied by different political purposes. (Khaji, 2012: 24). Embargo has been a kind of nonmilitary measure under article 41 of Un charter that is predicted for bringing pressure and enforcing states who breach peace and invade other states consisted of prohibiting exports or imports of all or part of required and necessary productions and goods of embargoed states and constraint or banning some of the activities in embargoed state. Mainly, Economic embargo is considered as an alternative to war and applying force and contain different kinds of economic relations either trade or financial. Different states imposed limited embargo sanction for their political purposes against targeted states; however, this kind of embargos are generally ineffective (Lopez, 2000, 254-56). Multilateral embargo are rarely taken by international bodies. Economic embargo are generally of two kinds or applied on two areas:

$1^{\text {st }}$, trade embargo in which the exports or imports to targeted states is limited or halted, $2^{\text {nd }}$, restricting or halting financial ties. On the other hand, economic embargo is divided into 3 sections based on the origin of embargo: 1) unilateral embargo 2) embargo by couples of states 3) embargo by UN Security Council (Momtaz, 2013: 165). There is difference between strategic and non-strategic purposes. Since embargo for strategic purposes often substitute for war hence, its financial costs is rather limited and also justifiable for embargoing states. Economic embargo for strategic purposes passes through four stages:

1) Encouraging targeted states in private and via bilateral negotiation

2) Overt request of target state and public announcement

3) Consulting alliances for further measures and military act just in case!

4) Initiating embargo from non-economical level (Drezner, 1999: 69-73).

Spreading the employment of economic embargo in international relations in $20^{\text {th }}$ century raises this question that whether economic embargo contain necessary legitimacy in international laws? Accordingly, through garnering different insights, 3 theories can be extracted that is explicated respectively.

\section{Theory of Absolut Legitimacy of Economic Sanction}

The cornerstone of this theory is rooted in "state sovereignty principle" in international law. Principally, "sovereignty principle" (Westphalian sovereignty) ${ }^{2}$ is identified as an independence and freedom from foreign hegemony to determine their internal and foreign policies and state equality in accordance with law. (Carter Barry, 2002: 243). Therefore, states benefit from necessary jurisdiction for applying their sovereignty right in their internal territory. Natural and economic resources are contained in "state sovereignty principle". This fact has been emphasized in resolution 1803 of 14 December 1962 under " state sovereignty on its natural resources" by UN general assembly. Therefore, states in accordance with sovereignty principle on their own natural resources are authorized to establish or halt economic relation in the form of economic embargo with another state. Sovereignty principle that emanates from positivism perspective in international law does not regard trade refusal with other states as an illegal act irrespective of consequences and effects it may imposed on other states (Reisman, 1998: 56).

In effect, in accordance with article 2(1) of UN charter " the organization shall be rested upon the principle of sovereignty equality of all members" the states sovereignty under international law is regarded to be in equal status (level). Non-intervention principle arises from sovereignty principles. Namely, according to principles of UN charter, states sovereignty is defined in an equal level across all state parties and in accordance with sovereignty equality the states are

${ }^{2}$ Westphalian sovereignty is the principle of international law that each nation state has sovereignty over its territory and domestic affairs, to the exclusion of all external powers, on the principle of non-interference in another country's domestic affairs, and that each state (no matter how large or small) is equal in international law. The doctrine is named after the Peace of Westphalia, signed in 1648. 
prohibited from interfering in each other affairs, therefore, prohibiting from trade with other member is contained within sovereignty jurisdiction. Hence, restrain trade with other is within sovereignty internal and voluntary jurisdiction. (Zahrani, 1997: 117-124). Not only is economic embargo not prohibited in international law, but also every issue that is incorporated under international law testify this fact and are contained within states jurisdiction in accordance with "state sovereignty principle". This opinion is also confirmed in Nicaragua case by international court of justice. Therefore, states have freedom to conduct their expedient behavior within the framework of sovereignty jurisdiction.

\section{Theory of Relative Legitimacy of Economic Sanctions}

Nowadays, despite relative progress in international law, lack of sufficient sanction (performance bond) across UN levels, economic embargo is represented as an effective measure toward restoring international order and penalizing transgressor states by other states. Hence, despite the fact that embargo is an illegal act in the light of international law, states can resort to embargo with respect to mutual measures against states contriving international law. So, in the absence of effective international sanction against contravening state parties, economic embargo by other states shall contain legitimacy and legal credibility and is not in contrast with international law. Unlike previous insights concerning legitimacy of embargo in international law, the legitimacy of embargo is not necessarily absolute but is authorized under specific condition. In effect, then the mutual measure of states that is represented via economic embargo is codified by convention of international law. So, compliance with the rule is the most significant factor that has to be incorporated within state's countermeasure (Momtaz, 1999: 18).

No state can resort to breach Jus cogens ${ }^{3}$ of international law in order to prevent the violation of international law. In none of international documents; however, the Jus cogens has been considered. Based on article 53 of Vienna convention on the law of treaties Jus cogens is generally confirmed and ratified by international societies and the least breach shall not authorized and its change is possible either through other international rules or Jus cogens features itself. Besides mutual respect for the international Jus cogens in countermeasure, the convention project of international law concerning state parties international responsibilities under article 50 (2), the state shall resolve disputes among aggrieved parties and the targeted state of countermeasure. In accordance with this paragraph, if states desire to countermeasure against another state, reference procedure of dissolving disputes is available in a form of binding and precedent to any measure the dispute shall be taken to that authority (Haddadi, 2003:116).

However, applied multilateral economic embargo by Security Council has provoked plenty of doubts concerning the legitimacy of this action and its sharp contrast with general international law principles, jus conges and human rights. Since during the codification of UN charter and related issues regarding economic embargo " the individual reflection has not been represented as subject of international law and individual rights were supposed to contain within state's internal jurisdiction, accordingly, the silence of the charter shall be attributed to traditional approach to state sovereignty principle"(Momtaz, 2008, 344).

\section{The theory of the illegitimacy of economic sanctions:}

Unlike the absolute legitimacy of economic sanctions in the eyes of international law that is based on a broad interpretation of the sovereignty of nations, this theory rejects any intervention in sovereign states, including the competence of countries in the economic and trade relations based the principle of non-intervention and its relation with economic sanctions. Article 32 of the Charter of Economic Rights and Duties of States provides that no government may uses economic, political measures or any other type of measures to coerce another state to the exercise its sovereignty for obedience. This is stress in the resolution 2131 of General Assembly in 1956 that no state has no right to directly or indirectly, for any reason, interfere in the internal affairs of another state. Therefore, economic sanctions, especially secondary ones sanctions against third party of economic objective is violating the principle of non-intervention (E lliot Kimberly, 1996: 113).

The economic sanctions by entering the domain of those matters falling within the domestic jurisdiction of a country violate the freedom of a country's economic and financial relations in the international arena, which is in blatant contradiction with the principle of non-intervention in the affairs of each other stemming from the principle of the sovereign equality of sovereignty and international law. In addition to the obligation of states to refrain from the use of force based on paragraph 4 of Article 2 of the UN Charter. It includes not only military force, but all aspects including political and

\footnotetext{
${ }^{3} \mathrm{~A}$ peremptory norm (also called jus cogens or ius cogens) is a fundamental principle of international law that is accepted by the international community of states as a norm from which no derogation is permitted.
} 
economic force. The Declaration of 1970, which contains a prohibition on the use of force by the military and the political or in any other manner provides that the use of economic sanctions, in which a force is hidden, is illegal and has no legitimacy on the basis of the UN Charter (Hufbauer, 2001: 54-56).

\section{International Economic law and the illegitimacy of economic sanctions}

International economic law has widely been conceived in terms of a branch of international law; alongside such other branches like international humanitarian law, international human rights law, international law of the sea, etc. In which case, it stands on the pivot of international law, while keeping its particular peculiarities. These peculiarities expose its content and concern to the economic development of states as structured by the international community. International economic law is part of public international law that investigates those general rules of international law which deals directly with the economic exchange between subjects of international law. New international economic order after the Second World War led to the establishment of a market economy led by America and the industrial government based on competition and the free market from the national level to the global level in terms of international economic organizations such as the IMF and GATT leads (Kelk Din, Alan Palais, 2004: 553).

However, the economic sanctions that are characterized by the distortion of a country's economy in the form of restrictions on imports and exports are targeted sanctions in apparent contradiction with the current international economic system founded by the West. In a sense, economic sanctions is in conflict with the principle of economic freedom that is one of the manifestations of the freedom of individuals. By accepting these terms and extending it in the form of induction into the international economic system, the country has the right to freedom of trade and any violation of their freedom is violation of their basic rights.

In the search for economic sovereignty, developing states supported and pushed for the establishment of the New International Economic Order ${ }^{4}$. This "new" order emphasized the permanent sovereignty of states over natural resources. In pursuit of New International Economic Order, other emphases relating to environment and sustainable development also developed. Following from these developments, a state that is desirous of economic development can tap into these rights; to wit.

- Permanent sovereignty over its natural resources

- Sovereignty over the non-natural resources or economic activities within its territorial jurisdiction; including its human resources

- Inalienable right to choose and conduct its own economic self-determination and governance

- Rights of non-interference in its economic affairs through the threat or use of force (Qureshi, 2007: 35).

In such circumstances, sanctions are in gross conflict with the interdependence of economy of countries formed after the Second World War in a market economy by expanding economic exchanges in accordance with the law of comparative advantage. Now as a result of the expansion of free trade, no country can claim to have independence from other countries even big countries like America is so tied to as China's economy that is even hard to talk of a split of America's economy of other economies. It can be economic interdependence, which is derived from the freedom of international trade, one of the principles of the current global economy. However, as a result of sanctions targeting the country's economy, economic interdependence on each other resulting from international division of labor, does not stop the effects of sanctions within one country but extends them to the entire international economic system. As America suffered hazards of oil sanctions against Iran due to oil price volatility caused by fluctuations in market supply and demand will not only be felt Iran but also endanger America's interests (Katzman, 2014).

In general, it seems that economic sanctions from the perspective of international law that based on the principles of neo-classical economics, economic sanctions are in apparent contradiction with free trade and the sovereignty of countries. However, the need is strongly felt for a global framework for international trade to provide international peace and stability through economic cooperation between the countries. As the meaning in the third paragraph of Article I of the United Nations Charter, to "achieve international cooperation in solving international problems of an economic, social, cultural or humanitarian nature, and in promoting and encouraging respect for human rights and fundamental freedoms "it is emphasized.to provide a context of increasing international cooperation through the promotion of economic exchanges between the countries to reduce disparities and factors causing tension between countries"( Raustiala, 2003: 78).

\footnotetext{
${ }^{4}$ The New International Economic Order (NIEO) was a set of proposals put forward during the 1970s by some developing countries through the United Nations Conference on Trade and Development to promote their interests by improving their terms of trade, increasing development assistance, developedcountry tariff reductions, and other means. It was meant to be a revision of the international economic system in favor of Third World countries, replacing the Bretton Woods system, which had benefited the leading states that had created it - especially the United States.
} 


\section{Unilateral sanctions against Iran from the perspective of international law}

Irrespective of legality or illegality of referral the Iranian nuclear issue to the Security Council on the basis of the IAEA Statute and the NPT, and irrespective of whether the Council is totally free in exercising its powers or is bound to the provisions of the Charter as a whole, it should be noticed that unfortunately some states such as the U.S and group of states i.e. the E.U have gone beyond the sanction resolutions of the S.C and imposed unilateral sanctions against Iran .The economic sanctions imposed after the First World War are 183 in number, the 140 of which have been made by the United States. Economic sanctions have never been the best way to resolve international conflicts, but always the last method is to use force. Since 1990s, Iraq, Yugoslavia, Greece, Libya, Liberia, Haiti, front UNITA in Angola, Somalia, Rwanda, Sierra Leone, Afghanistan, Taliban and al-Qaeda, Congo, Sudan, some citizens of Lebanon, North Korea and Iran have been subject to the Security Council United Nations sanctions (www.un.org, 2014).

However, as for unilateral sanctions, according Richard Cheney former US Secretary of Defense, "more than 70 countries with two-thirds of the world's population are affected by the US sanctions." On November 1979, less than two weeks and three days after the arrival of the Shah's visit to the United States, Algeria, 400 Muslim students who call themselves "Muslim Students Following the Line of the Imam" joined the protesters against the US Embassy and 53 of them entered the embassy and took Americans hostage at the US Embassy, demanding the extradition of the Shah. Hostage crisis lasted 444 days. Embassy row immediately affect US-Iranian relations. US-Iran relations were cut and the US made political, economic, legal and military sanctions against Iran. Although the hostages were freed on 19 January 1981, but punishment of Iran continues (Calamita, 2009: 5).

US economic sanctions against Iran should be considered by Iran in recent decades as the result of its unreasonable behavior. The US believes by adopting methods that violate international law, Iran after the revolution has caused the United States material and intellectual damage, including diplomatic and consular rights abuses, support for terrorism, disrupting the Middle East peace process and efforts by Iran to acquire nuclear weapons are accusations that justifies reciprocity by US against Iran. Given this introduction about US sanctions against Iran, it should be noted that those sanctions outside the framework of resolutions 1737 and 1747 caused "indirect" intervention by the US in "internal" and "external" affairs of Iran, as the activities of the military (Iran's Revolutionary Guards) and state bank are an integral part of the internal affairs, as Iran has not only avoided sharing its financial and military relations with any country or organization using optional international mechanism but also different treaties and conventions stress such power and freedom of the country(Mafi, 2007: 86). By the way, the indicators have shown the US sanctions against Iran from the Iranian revolution.

\begin{tabular}{|c|c|c|}
\hline Name & Date & Description of select elements \\
\hline $\begin{array}{l}\text { Executive Orders } \\
12170,12205 \\
12211\end{array}$ & $\begin{array}{l}\text { Nov. 1979- } \\
\text { April } 1980\end{array}$ & $\begin{array}{l}\text { - Blocked Iranian property and } \\
\text { prohibited some trade, including } \\
\text { import of all goods from Iran. } \\
\text { Bons lifted under Ngers Acconds in } 1991 .\end{array}$ \\
\hline $\begin{array}{l}\text { State Sponsor of } \\
\text { Terror designation }\end{array}$ & $\begin{array}{l}\text { January } \\
1984\end{array}$ & $\begin{array}{l}\text { - Banned arms sales and foreign } \\
\text { assistance to Iran. }\end{array}$ \\
\hline $\begin{array}{l}\text { Executive Order } \\
12613\end{array}$ & $\begin{array}{l}\text { October } \\
1987\end{array}$ & $\begin{array}{l}\text { - Banned import of all goods from Iran, } \\
\text { including oil. }\end{array}$ \\
\hline $\begin{array}{l}\text { Iran-Iraq Arms Non- } \\
\text { Proliferation Act }\end{array}$ & $\begin{array}{l}\text { October } \\
1992\end{array}$ & $\begin{array}{l}\text { - Sanctioned transfer of goods or } \\
\text { technology related to WMD and some } \\
\text { conventional arms. }\end{array}$ \\
\hline $\begin{array}{l}\text { Executive Order } \\
12938\end{array}$ & $\begin{array}{c}\text { November } \\
1994\end{array}$ & $\begin{array}{l}\text { Imposed export controls on sensitive } \\
\text { WMD technology. }\end{array}$ \\
\hline $\begin{array}{l}\text { Executive Orders } \\
12957,12959\end{array}$ & $\begin{array}{l}\text { March-May } \\
1995\end{array}$ & $\begin{array}{l}\text { - Prohibited all U.S. investment in Iran, } \\
\text { including in oil sector. } \\
\text { - Banned export of American goods } \\
\text { to Iran. }\end{array}$ \\
\hline $\begin{array}{l}\text { Iran and Libya } \\
\text { Sanctions Act }\end{array}$ & $\begin{array}{c}\text { August } \\
1996\end{array}$ & $\begin{array}{l}\text { - Sanctioned companies that invest } \\
\text { more than } \$ 20 \text { million in Iranian oil } \\
\text { sector. }\end{array}$ \\
\hline $\begin{array}{l}\text { Executive Order } \\
13059\end{array}$ & $\begin{array}{c}\text { August } \\
1997\end{array}$ & - Expanded ban on exports to lran. \\
\hline $\begin{array}{l}\text { Iran Non- } \\
\text { proliferation Act }\end{array}$ & $\begin{array}{l}\text { March } \\
2000\end{array}$ & $\begin{array}{l}\text { - Sanctioned entities providing goods } \\
\text { related to WMD or ballistic missiles. }\end{array}$ \\
\hline $\begin{array}{l}\text { Executive Order } \\
13224\end{array}$ & $\begin{array}{l}\text { September } \\
2001\end{array}$ & $\begin{array}{l}\text { - Blocked property of terrorists and } \\
\text { financial supporters. }\end{array}$ \\
\hline $\begin{array}{l}\text { Executive Order } \\
13382\end{array}$ & June 2005 & - Blocked property of WMD proliferators. \\
\hline
\end{tabular}

Figure (1): Major U.S. Sanctions Actions, 1979-2005

Sources: Belfer Center for Science and International Affairs, 2010 
Pressures imposed by the US against Iran's Revolutionary Guards and banks with respect to the said and unsaid objectives of the US constitutes intervention in both the internal affairs and foreign affairs and the jurisdiction of the country, by sanctions, the US tries to increase the economic difficulties and consequently, the regime change and has caused international trade relations of Iran to face difficulties. Problems such as bearing additional costs for the preparation of conventional military equipment and money convertibility of the dollar to other units, expenses related to speculators, incentive policies for foreign investment, all of which are costly for Iran and are caused by sanctions. For this reason, in the past, Iran brought a suit against the US to Court of Arbitration mostly based on principle of noninterference, which is largely based on citations of resolutions and different views and "legal opinion" ( Neff, 2012: 54-59). The suit is now in the process. Here are some information and indicators that show the US unilateral sanctions against Iran after intensifying Iranian nuclear program issues.

\begin{tabular}{|c|c|c|}
\hline Name & Date & Description of select elements \\
\hline $\begin{array}{l}\text { Iran Freedom } \\
\text { Support Act }\end{array}$ & $\begin{array}{l}\text { September } \\
2006\end{array}$ & $\begin{array}{l}\text { - Sanctioned involvement in Iranian } \\
\text { development of WMD/advanced } \\
\text { conventional weapons. } \\
\text {. Codified U.S. trade ban. }\end{array}$ \\
\hline $\begin{array}{l}\text { Executive Order } \\
13438\end{array}$ & July 2007 & $\begin{array}{l}\text { - Blocked property of those involved in } \\
\text { destabilizing lraq. }\end{array}$ \\
\hline $\begin{array}{l}\text { Comprehensive } \\
\text { Iran Sanctions, } \\
\text { Accountability \& } \\
\text { Divestment Act }\end{array}$ & July 2010 & $\begin{array}{l}\text { - Sanctioned sale to Iran of gasoline or } \\
\text { supporting domestic gasoline industry. } \\
\text { - Sanctioned foreign financial institutions } \\
\text { connected with WMD or terrorism. }\end{array}$ \\
\hline $\begin{array}{l}\text { Executive Order } \\
13553\end{array}$ & $\begin{array}{l}\text { September } \\
2010\end{array}$ & $\begin{array}{l}\text { Blocked property of those involved in } \\
\text { human rights abuses in Iran. }\end{array}$ \\
\hline $\begin{array}{l}\text { Executive Order } \\
13572\end{array}$ & April 2011 & $\begin{array}{l}\text { Blocked property of those involved in } \\
\text { human rights abuses in Syria, including } \\
\text { Iranians. }\end{array}$ \\
\hline $\begin{array}{l}\text { Executive Order } \\
13590\end{array}$ & $\begin{array}{l}\text { November } \\
2011\end{array}$ & $\begin{array}{l}\text { - Sanctioned contributing to maintenance } \\
\text { or expansion of Iranian petroleum } \\
\text { resources. }\end{array}$ \\
\hline $\begin{array}{l}\text { Sect. } 311 \text { Money } \\
\text { Laundering } \\
\text { designation, USA } \\
\text { PATRIOT Act }\end{array}$ & $\begin{array}{l}\text { November } \\
2011\end{array}$ & $\begin{array}{l}\text { Designated Iranian financial sector as } \\
\text { jurisdiction of "primary money laundering } \\
\text { concern:" }\end{array}$ \\
\hline $\begin{array}{l}\text { Section } 1245, \\
\text { NDAA FY } 2012\end{array}$ & $\begin{array}{l}\text { December } \\
2011\end{array}$ & $\begin{array}{l}\text { - Restricted export of Iranian oil. } \\
\text { Codified Section } 311 \text { Money Laundering } \\
\text { designation. }\end{array}$ \\
\hline Name & Date & Description of select elements \\
\hline $\begin{array}{l}\text { Executive Order } \\
13599\end{array}$ & $\begin{array}{c}\text { February } \\
2012\end{array}$ & $\begin{array}{l}\text { - Blocked all Iranian government property } \\
\text { under U.S. jurisdiction. }\end{array}$ \\
\hline $\begin{array}{l}\text { Executive Order } \\
13606\end{array}$ & April 2012 & $\begin{array}{l}\text { Blocked property of those involved with } \\
\text { human rights abuses perpetrated through } \\
\text { information technology. }\end{array}$ \\
\hline $\begin{array}{l}\text { Executive Order } \\
13608\end{array}$ & May 2012 & - Sanctioned evaders of sanctions. \\
\hline $\begin{array}{l}\text { Executive Order } \\
13622\end{array}$ & July 2012 & $\begin{array}{l}\text { - Sanctioned foreign financial institutions } \\
\text { that facilitate petroleum sales. }\end{array}$ \\
\hline $\begin{array}{l}\text { Iran Threat } \\
\text { Reduction and } \\
\text { Syria Human } \\
\text { Rights Act of } 2012\end{array}$ & $\begin{array}{c}\text { August } \\
2012\end{array}$ & $\begin{array}{l}\text { - Sanctioned support of petroleum sector. } \\
\text { Mandated that Iran's oil revenue be } \\
\text { "locked up" in special escrow accounts. }\end{array}$ \\
\hline $\begin{array}{l}\text { Executive Order } \\
13628\end{array}$ & $\begin{array}{c}\text { October } \\
2012\end{array}$ & $\begin{array}{l}\text { - Expanded Iran Threat Reduction and Syria } \\
\text { Human Rights Act }\end{array}$ \\
\hline $\begin{array}{l}\text { Iran Freedom } \\
\text { and Counter- } \\
\text { Proliferation Act } \\
\text { of } \mathbf{2 0 1 2}\end{array}$ & $\begin{array}{l}\text { January } \\
2013\end{array}$ & $\begin{array}{l}\text { Sanctioned involvement in Iranian energy. } \\
\text { shipping or shipbuilding, or provision } \\
\text { of insurance or reinsurance to shipping } \\
\text { firms. } \\
\text { - Sanctioned provision of precious metals } \\
\text { to Iran. }\end{array}$ \\
\hline $\begin{array}{l}\text { Executive Order } \\
13645\end{array}$ & June 2013 & $\begin{array}{l}\text { - Sanctioned involvement in Iranian } \\
\text { automotive industry. } \\
\text { - Blocked assets of banks doing business in } \\
\text { rials, the currency of Iran. }\end{array}$ \\
\hline
\end{tabular}

Figure (2): Major U.S. Sanctions Actions, 2006-present

Sources: Belfer Center for Science and International Affairs, 2014 
Economic sanctions that are not a peaceful method for solving international disputes or compensation is based basic principles of charter. United Nations Conference on Trade and Development (UNCTAD) stated based on this fact in a resolution that "These measures do not help to create a peaceful atmosphere which is necessary for development". UNCTAD in the resolution titled "rejection of coercive economic measures" stated: "All developed countries should avoid trade restrictions, blockades, bans on trade and other economic sanctions incompatible with the provisions of the UN Charter against developing countries, as a form of political coercion which affect the economic and social development of these countries". Of course, as mentioned in the resolution with the phrase "political persuasion", such measure is indisputable if it is in line with the regulation of economic relations and for economic purposes but when it has political intentions, it contradicts freedom of trade said in resolution.

The General Assembly has repeatedly denounced taking coercive economic measures as a means of achieving political goals (Neff, 1391: 54-59). In addition to the above-mentioned, unilateral illegitimate economic sanctions without a legal basis can damage other rights such as the system of international human rights, the airline industry, for example, has been affected US sanctions on the Islamic Republic of Iran has, according to Transport Minister, so that air travelers lives is endangered and the violation of the right to security and life have been compromised.

\section{The effects of economic sanctions on Iran}

Multilateral and unilateral economic sanctions against Iran cause stagnation in the industrial, commercial and general economic rates. Either unilateral or multilateral, sanctions since Iran's Islamic Revolution have been the core of United States policy toward Iran. When Barack Obama, the current President of America, first entered the White House, said he had plans to pursue a policy of engagement with Iran. But in the first round of his presidency, the toughest sanctions against Iran were imposed. Iran's nuclear progress at the time of the imposition of sanctions leaves no doubt that force exerted by the West is an important factor in pushing Iran toward self-sufficiency in nuclear technology. A similar phenomenon occurred during the Iran-Iraq war. Before the conflict, Iran could not produce even a single bullet and was completely dependent on western weapons. But during the war and after it, despite the increased sanctions, Iran has a large defense industry and self-sufficiency in the production of weapons. Iran has long-range missiles and even sent a satellite into space (Amuzegar, 2013: 8).

According to reports of the International Agency for Atomic Energy, before sanctions related to the nuclear issue, Iran only had one center for uranium enrichment and has 164 operating centrifuges that enriched uranium to a level 3.5\% enriched, with a generation of centrifuge plants and about 100 kilograms of enriched uranium stored. Today, after the sanctions, Iran has two centers and approximately 12,000 centrifuge, the enrichment level of about 20 percent, a new generation of centrifuges and reserves amounting to 8,000 kilograms of uranium enriched. In recent agreement, the number of reactors in Arak and Natanz, as well as the enrichment have been adjusted. Iran's nuclear progress under increasing sanctions and threats of force prove beyond doubt the most important factor in encouraging Iran to develop the skills and self-sufficiency in nuclear technology (Haidar, 2015).

As a result of sanctions strategy, economic and industrial growth reduced, foreign investment was limited, the currency weakened, inflation multiplied and export of oil and gas was reduced. Mahmoud Bahmani, the head Central Bank of the Islamic Republic, said in describing the effect of the sanctions that the sanctions are nothing less than a military war. The sanctions have destroyed the middle class society and marginalized the private sector in favor of the public sector. Moreover, sanctions pushed trade outside the formal banking system and to the underground network (Timothy, 2013: 3). As a result of sanctions, the West will force Iran to distance itself from the market economy. More than the banking sanctions and financial problems which Iran has faced with, the Oil productions that shape the majority of Iranian income, have been experiencing the lowest level in the period of sanctions, this stagnation in the production and selling of Iranian oil clarified by following figure: 


\begin{tabular}{|c|c|c|c|}
\hline Buyer & $\begin{array}{l}\text { Average Pre- } \\
\text { Sanctions (2011) }\end{array}$ & $\begin{array}{l}\text { Average Post- } \\
\text { Interim Agreement } \\
\text { (2014-present) }\end{array}$ & $\begin{array}{l}\text { Percent } \\
\text { change }\end{array}$ \\
\hline European Union & 600,000 & Negligible & $-100 \%$ \\
\hline China & 550,000 & 410,000 & $-25 \%$ \\
\hline Japan & 325,000 & 190,000 & $-40 \%$ \\
\hline India & 320,000 & 190,000 & $-40 \%$ \\
\hline South Korea & 230,000 & 130,000 & $-40 \%$ \\
\hline Turkey & 200,000 & 120,000 & $-40 \%$ \\
\hline South Africa & 80,000 & o & $-100 \%$ \\
\hline Malaysia & 55,000 & o & $-100 \%$ \\
\hline Sri Lanka & 35,000 & Negligible & $-100 \%$ \\
\hline Taiwan & 35,000 & 10,000 & $-70 \%$ \\
\hline Singapore & 20,000 & o & $-100 \%$ \\
\hline Other & 55,000 & Negligible & $-100 \%$ \\
\hline Total & 2.505 million & 1.057 million & $-60 \%$ \\
\hline
\end{tabular}

Figure (3): Crude Oil Exports, Pre- and Post-Sanctions

Source: International Energy Agency; Congressional Research Service, 2015

Economically, unilateral and multilateral sanctions imposed by the big powers and the international financial and economic institutions have developed economic relations with the East, particularly their rival, China. Since 2001, China's exports to Iran has almost 16 -folded. At a recent meeting of Europe, I reminded my European friends that Europe's share of the economy in 1990 amounted to 50 percent. But because of sanctions today China has $50 \%$ of Iran's foreign trade and Europe has lost its influence on the Iranian economy. In other words, the west made sanctions without influence and instead puts the position of major competitors, such as China, Russia and India in a better place in the economy. International trade sanctions have shifted Iran from West to East. In fact, Iran has adopted policy of tendency to East or Asia. And sociologically, mastering the core technology has become a matter of national pride. The vast majority of people support Iran's nuclear program. A survey conducted in December 2012 by Gallup shows that despite the sanctions, 63 percent of the people of Iran prefer Iran to continue its nuclear program. Only 17 percent are opposed to nuclear programs. Similar to that occurred in the 1950s during the movement for the nationalization of the oil industry; domination and bullying and sanctions of foreigners led to increased support from Iranians for the government (Nasseri, 2012: May 26). Moreover, the imposed sanctions created spaces for stagnating Iranian export and economic exchanges with its partners in the global economy sphere. Following figure shows reduction in Iranian Export indicators due to nuclear conflict and imposing sanctions:

\begin{tabular}{|c|c|c|c|}
\hline Global & $\begin{array}{l}\text { Exports in } 2011 \\
\text { Uss million }\end{array}$ & $\begin{array}{l}\text { Estimated coefficient } \\
\text { on sanctions }\end{array}$ & $\begin{array}{l}\text { Estimated loss of } \\
\text { exports in } 2012 \cdot 14 \\
\text { USS million }\end{array}$ \\
\hline Japan & 11,688 & -0.5 & 7,542 \\
\hline South Korea & 10,303 & -0.3 & 4,403 \\
\hline Italy & 6,762 & -2.1 & 2,899 \\
\hline Singapore & 2,022 & -3.8 & 979 \\
\hline Germany & 907 & .0 .8 & 535 \\
\hline France & 2,225 & -3.6 & 214 \\
\hline US & 1 & -2.8 & 4 \\
\hline UK & 525 & -1.1 & 165 \\
\hline Netherlands & 2,000 & -3.4 & 307 \\
\hline \multicolumn{4}{|l|}{ MENA region } \\
\hline Morocco & 10 & -5.0 & 3 \\
\hline Qatar & 58 & -0.6 & 57 \\
\hline Tunisia & 8 & -0.7 & 7 \\
\hline Total & & & 17,114 \\
\hline
\end{tabular}

Figure (4): Iran's exports loss due to international sanctions during 2012-14

Source: Mottaghi (2015). The percentage change in trade is calculated by taking the exponent of the coefficient value for the dummy and subtracting.

Economic sanctions imposed by the US and international economic institutions cause bottlenecks in the purchase and import of goods from abroad for the Islamic Republic of Iran. The distribution system disorder, hoarding and profiteering, the emergence of a black market for many goods and trade committee and revolutionary courts have been drivers of that 
bottleneck. Moreover, due to sanctions imposed by America, Iran will have to pay more for imported goods. In this regard, one of the results of economic sanctions against Iran, the United States and its allies over the past decades, has been the devaluation of the Iranian Rial. Devaluation of the Rial also leads to reduction of the imports and limiting Iran's access to capital and foreign technology. In other words, the United States and its allies in the previous sanctions has changed Iran's investment atmosphere, and with the transfer of technology to Iran is not done. In the same decade, the sanctions forced Iran to stop part of the plans for the structural development of the economy after the war (Katzman, 2012: 13-23).

In general, the effects of the sanctions in the short term in some cases resulted in a strain on the financial system of the Islamic Republic of Iran and transaction costs and ultimately prices have increased. In the medium-term effects, the effects of the sanctions reduced investment, slowed growth and increased inflation. In this regard, the Islamic Republic in some cases has seen a decline in the volume of imports and exports and foreign exchange reserves. The second aspect of the embargo, no doubt, is due to the effects of the sanctions that can be revealed. Because enforcement of sanctions not only failed to alter the behavior of the Islamic Republic of Iran in a way that America and its allies are expecting, but in some cases, Iran has been healthier and more stable than many developing countries that receive help from the US. This is due to the need to adopt a system of cooperation of the international community and divergence approach. Basically, without the full cooperation of all potential trading partners, the damage to the export or import of a country through sanctions is difficult to achieve.

In this regard, although economic sanctions caused damages often to economy of country but it also has its costs for those imposing them. For example, US sanctions primarily affect the country's oil companies. These companies in recent years have purchased close to 5.3 billion dollars' worth of crude oil from Iran. Estimates show that the sanctions imposed by America on Iran and Libya and Syria resulted in America's annual $\$ 7$ billion in damage and loss of 200,000 jobs in this country (Johnson, 1997: 16). A study by the Institute for International Economics suggests that the cost of sanctions for US companies in 1995 alone is about 15 to 19 billion dollars.

\section{Iran's Nuclear Deal with the P5 + 1, Lifting of Sanctions and its Possible Effects}

Iran is a country with 78 million inhabitants and has the twenty-seventh of the world's GDP. According to the central bank, $52 \%$ of national income comes from the service sector, $18 \%$ oil, $13 \%$ industry, 12\% in agriculture and 5 percent from construction. Many Western companies are willing to invest in Iran, particularly in the oil sector and industry. The nuclear deal results in political changes after which the incentives will improve the business and investment. If investment and consumer goods production and employment also increase due to foreign investment in Iran, strained relations with the West will be less for the government and this is what will be good for Iran. Some are against the deal in Iran, but many people want to come out of international isolation and want the economic corruption to be reduced. Similarly, many of America's Republicans are opposed to this deal, without hearing the voice of American companies that can benefit from the relationship with Iran, although process of lifting sanctions is time-consuming, but Europe and the America will be pleased with an emerging market in the future(Abdi and Cullis, 2014: October 14).

The first effect of the lifting of sanctions is increase of Iran's oil exports to the world. Iran's oil exports are expected to double within a year. Like in the years between 2009-2001 Iran daily exports can rise to three and a half million barrels of oil, two million barrels of which will be exported, while this figure had been halved due to sanctions since 2010. Upon lifting of sanctions, foreign investors in the oil industry can bring new technologies in the field of oil fields, thus reviving oil. The increase in exports could send oil prices below $\$ 40$ a barrel next year. This is a positive shock for oil-importing countries and a negative shock to the oil-exporting countries. $\$ 10$ reduction in the price of oil shifts half percent of GDP growth from exporting countries to importing countries. That is, growth of oil exporters is reduced by half a percentage, while the opposite occurs to importers, adding half a percentage point to their growth. It can actually act like a tax cut of trillions of dollars. While many industrialized countries have focused on reducing the budget deficit, they will have the power not to cut taxes. The main winners of the game will be Japan, India and major European countries that import oil. America will benefit as well, because it is still imports a third of its oil requirement (Donnelly, 2014:23).

Regardless of imposing countries and organizations, sanctions can be divided into 6 groups: banking sanctions, dual-use goods and military sanctions, sanctions on oil and petrochemical industry, sanctions on military goods arms, sanctions on certain companies, institutions and sanctions of certain individuals. In the above sanctions, effective sanctions on the economy are situation of the first, second and third types, which have detrimental effects on the economy. Other psychological effects of sanctions on the Iranian economy had little effect and in some cases, especially in case military equipment, stimulates greater reliance on domestic resources and causes progress. In fact, the most effective sanctions are the banking sanctions that because there is no alternative to banks in the international financial and monetary relations in connection with the world economy, such sanctions cause a lot of problems and impose heavy 
costs on the country. Among the effects of such sanctions are effect on Iran's foreign exchange revenues, lack of access to international financial resources, lack of implementation of international regular transactions through credit and cash payments to foreign vendors, risky and unconventional channels and major corruption associated with it, as well as the lack of use of international credit cards and barriers to attracting tourists to Iran. In terms of exports, collection of income from exports faces many problems, instead of producers and exporters collecting the income, the export broker increases in number. Sanction on dual-use goods in itself is not problematic, but bureaucracy of recognition and licensing in countries of origin exporting to Iran increases delivery time and wastes time and given the cash payment of the cost of goods, it results in high loss for the manufactories of Iran and caused much delay.

Among the sanctions on industry, the most influential are those imposed on oil and gas and petrochemical industries that affect the industry and make their progress very slow. In other words, the above-mentioned three types of sanctions had great damage to international relations, financial and economic relations and economic growth in different parts of the country that their impact will continue for many years. Among these damages is forcing us to use low quality machinery and parts at a cost more expensive than some other countries, lagging behind the world's technology and industry, compensation for which takes the time, effort and high costs. Iran's restricted goods and export markets were also problems whose compensation requires great effort (Kattan, 2014).

Furthermore, some experts are believing that P5+1 agreement finally will impacts on general oil prices. These average price predictions are largely consistent with the discussion in two particular ways. First, experts anticipated that Iran would initially seek to "surge" oil onto the market after the signing of an agreement to demonstrate its geopolitical weight and ability to influence global markets. With very few exceptions, experts anticipated that the price would be lower six months after the deal than it would be a year after. Second, experts expected that, in the absence of a deal, there would be increased efforts to restrict Iranian oil sales and higher geopolitical risk in the region. (One expert, however, predicted less volatility.) Virtually all experts predicted that the "no deal" price would be higher than in either of the previous two scenarios. Following chart shows such predictions consequences on crude oil prices:

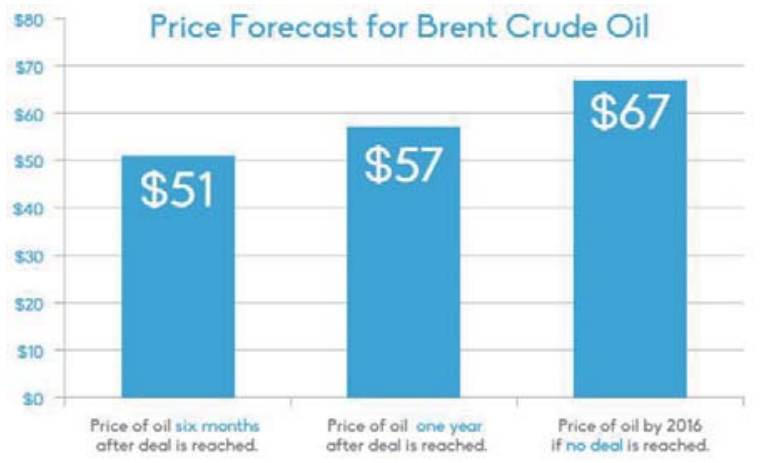

Chart (1): Forecasting crude oil price after the $P 5+1$ deal

Source: International Energy Agencies Projection, 2015

Iran's nuclear program during the last ten years has been one of the most important issues in international politics. On this basis, according to research, the recent negotiations can have multiple dimensions in the economy and international politics. The dimensions are classified into the followings:

- Global economic growth: While global economic is experience unprecedented recession, sanctions against Tehran increased the economic pressure on many countries and thus lifting the embargo on the possible deal could help economic growth. According to Iranian officials, on the eve of the deal, many foreign investors are already seeking to enter the market and conclude business contracts and thus with reduction of the economic pressure on Iran, global economic growth will accelerate.

- Control of Middle East crisis: Iran and the P5 + 1 could increase Tehran's role in the region and thus reduce the volume of regional competition that is abused by terrorist groups. As US officials have also shown in their correspondence, Tehran wants to play a greater role in restoring stability to the Middle East and it is the indirect result of an agreement that can ease the pressure on Iran, and push the region out of the current inflammation and help resolve conflicts in Lebanon, Syria, Yemen, Bahrain, Iraq. 
- The oil market is waiting for a deal: In addition, a possible agreement in Vienna can bring stability to the oil market. So far because of the sanctions on Iran, some countries have remained unrivaled in the oil market and this is why we are now concerned about the nuclear deal. However, the resolution of nuclear issue can gradually revive Iran's position as a market regulator.

- Iran's role in reducing crisis of East-West relations: relations between Moscow and the West are in the worst condition since the collapse of the USSR, the Ukraine and the Russian embargo crisis has increased the gap between East and West to a worrying extent and in such circumstances, cooperation between Russia and America in the nuclear talks could help to resolve the crisis and signature of the deal promotes moderator's position of Iran and increases the hope for more cooperation between Washington and its European allies and Moscow.

- Europe's reduced concerns over energy crisis: Dispute between Russia and Europe has made the West concerned about energy dependence on Russia and so, it's been many years that with the arrival of the cold season, Westerners try to reduce escalation of tension with Moscow. The nuclear deal, in the long run, will be the basis for energy exports from Iran to Europe and reduce concerns about Europe's dependence on Russia.

- Political equation of West are subject to the Vienna deal: a possible agreement between Iran and the P5 + 1 could indirectly affect the relations of Europe and America; and in particular, in the forthcoming presidential elections in the US, the Democrats are in a better position following the deal with Iran. Overall, the nuclear deal weakened position of hardliners and pro-war lobbying in various countries and credit was give back to the fans of diplomacy and reduction of international conflicts (Mousaviyan, 2015).

\section{Conclusion}

With regard to sanctions against Iran, one of the objectives of economic sanctions imposed by the United States and its allies is to change behavior and economic war. In this regard, for reasons such as to compel Iran to abandon the bad policies against US, to punish Iran for unacceptable policies in the region, expressing even symbolic opposition to Iran in order to draw attention to a major pro-Israel groups are reasons for adopting sanctions by America and its allies against the Islamic Republic. However, according to evidence of international law, enforcement of such sanctions will have no legitimacy. In the final analysis, taking into account recent developments in international law based on the need to further expand international cooperation in all fields, especially in trade, in fair conditions, the governments are obliged not to resort to any kind of action that is inconsistent with international cooperation.

There is no doubt that international cooperation is one of the purposes of the United Nations and economic sanctions seriously threaten international cooperation, and that the spirit of the international economic order that is emerging is incompatible with such sanctions. Perhaps it can be said briefly that if the scholars of international law are divided on the interpretation of the legitimacy or illegitimacy of sanctions, there are several reasons certainly in this case that there is no doubt that sanctions can cause interruption in the process of international integration and ultimately impact international peace and security. On the other hand, it must be said that the unilateral sanctions of the US against Iran violates the principle of peaceful coexistence among states that require respect for the political principles of international law, the legal equality of states, non-interference, cooperation and friendship, respect for the sovereignty and territorial integrity of states among the members of the international community. This type of action lack international legitimacy due to the lack of legitimacy. For this reason, in the process of international sanctions, stress must be placed on aspects such as legality, necessity and proportionality, as well as the effects of sanctions on innocent civilians. The link between moral values and the idea of enforcement of international law through sanctions and effective monitoring of the use of economic sanctions are necessary to consider. The current international system requires mutual respect and courtesy to ensure cooperation between states due to the absence of a global authority and control of the national governments.

\section{References}

Abdi, Jamal, and Tyler Cullis, 2014, "NIAC Policy Memo: Barriers to Lifting U.S. Sanctions in a Final Deal with Iran," National Iranian American Council, March 18, 2014. As of October 20, 2014.

Amuzegar, J. 2013, Iran's economy facing a challenging year, Middle East Economic Survey, Retrieved May 29, 2013.

Calamita, Jansen Vanderbilt, 2009, Sanctions, Countermeasures, and the Iranian Nuclear Issue, N. Journal of Transnational Law, Volume 42, November 2009, Number 5.

Carter and Barrely, 1989, "International Economic Sanctions" (Cambridge University press: New York V.1 1989). 
Carter Barry. E, 2002, International Economic Sanction: Improving the haphazard U .S. Legal Regime.' Cambridge: Cambridge University Press.

Donnelly, John M. 2014, "Next Senate Could Vote on Any Iran Deal-Whether Obama Likes It or Not," CQ Roll Call, October 20, 2014. As of October 23, 2014.

Drezner, Daniel W. (1999), The Sanctions Paradox: Economic Statecraft and International RelationsL .catpbridge, UK: Cambridge University Press.

E lliot Kimberly Ann (1996). Towards-a Framework for Muilateral Sanctions. Atlanta: carter center.

Haidar, J.I., 2015."Sanctions and Exports Deflection: Evidence from Iran," Paris School of Economics, University of Paris 1 Pantheon Sorbonne, Mimeo.

Hufbauer Gary Clyde and Jeffrey Schott (2001). Using Sanctions to Fight Terrorism, Cambridge University Press.

IMF Direction of Trade Statistics via, 2014 "IHS Economics \& Country Risk," http://www.ihs.com/products/global-insight/index.

Kaempfer, William H. \& Anton D. Lowenberg (1998), The Theory of International Economic'Sanctions: A Public Choice Approach: Reply', American Economic Review.

Kattan, Ari, 2013, "Fact Sheet: Iran Sanctions," Center for Arms Control and Non-Proliferation, March 2013. As of October 13, 2014.

Katzman K, 2014, Iran Sanctions, March 18, 2014, Congressional Research Service 7-5700 www.crs.gov RS20871.

Katzman, Kenneth, (3 February 2011). "Summary" (PDF). Iran Sanctions. Congressional Research Service. Retrieved 13 February 2012.

Khaji, Gholamreza, 2012, Economic Sanction in the Light of International Law by Emphasizing on International Economic Law and Development Right, quarterly of economic law, No, 2, Vol, 19, winter 2012.

Lopez George A. and Cortright David (2000). The Sanctions Decade: Assessing UN Strategies in the 1990s .Boulder: Lynne Rienner press.

Macdonald. R. st. J.1987, ' Economic Sanctions in International System ' (the Canadian Year Book of International Law: 1987).

Mafi, Homayon, 2007, The Dilemma of US Economic Sanctions on Iran: An Iranian Perspective, the Iranian Journal of International Affairs Vol. XIX, No.4, Fall 2007.

Momtaz, Jamshid, 1999, Economic Sanction and International Law; the US intervention in Iran's internal affairs, Journal of Law and Politics faculty, No. 17, Vol. 6, Summer 1999.

Momtaz, Jamshid, 2013, unilateral Economic Sanction and outlaw of International Law, Center for Islamic revolution study, fall, 2013.

Nasseri, Ladane (26 January 2012). "Iran Central Bank Will Devalue Rial 8.5\% Against Dollar as Sanctions Bite". Bloomberg. Retrieved 26 January 2012.

Qureshi A.H. 2007, International Economic Law, London, Sweet and Maxwell, 2007. N. Journal of Transnational Law, Volume 42, November 2009, Number 5.

Raustiala, Kal, 2003, 'Rethinking the Sovereignty Debate in International Economic Law', Journal of International Economic Law, 2003, $6,4,841-78$.

Reisman Michael and douglas L. Stevich, 1998, 'the Applicability of International Law Standards to United Nations Economic Sanctions Programs', European J. of Int. Law 9 (1998).

Stewart, David P. 1984, The Iran-United States Claims Tribunal: Accomplishments and prospects in private investors Abroad-Problems and Solution in International (Business, Mattew Bender, New York, 1984).

Timothy Alexander Guzman (10 April 2013). "New Economic Sanctions on Iran, Washington's Regime Change Strategy". Global Research. Retrieved 5 May 2013.

World Bank, 2014 "World Bank Database," http://data.worldbank.org/ indicator/NY.GDP.MKTP.CD.

Zahrani, Mostfa, 1997, Economic Sanction Theories, Iranian Foreign Affairs Publication, Tehran, 1997. 